\title{
PERAN BUDAYA ORGANISASI DALAM MEWUJUDKAN VISI MISI PARTAI KEADILAN SEJAHTERA (PKS)
}

\author{
Much. Yulianto \\ Departemen Hubungan Internasional, FISIP Undip \\ email : myuliyanto@yahoo.com
}

\begin{abstract}
Prosperous Justice Party (PKS) as large organization has been putting the organizational culture as a primary need to build both institutional work and the dynamics activities of members that were managed to realize the vision and mission of the party. Organizational culture as an internal force as well as institutional capital to realize the vision and mission of the party should be able to be evaluated in presence and role in order to realize of the vision and mission of the organization.

This study aims to determine the role of organizational culture in realizing the vision and mission of PKS. This research is a qualitative descriptive study. The data collection was done by in-depth interviews.

The results showed: (1) organizational culture play a role in shaping the identity and character of party members; (2) The organizational culture also plays a role in encouraging loyalty and solidity of party members; (3) the organizational culture at PKS played role in strengthening the confidence of individual members.
\end{abstract}

\section{Keywords: organizational culture, vision and mission, the Prosperous Justice Party}

\section{PENDAHULUAN}

Partai Keadilan Sejahtera yang merupakan perubahan nama dari Partai Keadilan pasca Pemilihan Umum 1999 adalah merupakan partai politik yang lahir pasca Orde Baru. Partai ini didirikan para mantan aktifis keislaman di kampus-kampus yang tersebar di seluruh Indonesia. Mereka sebelumnya tergabung dalam kelompok kajian keislaman yang tumbuh subur di kampus awal 1990-an yakni Lembaga Dakwah Kampus dan selanjutnya mendirikan Kesatuan Aksi Mahasiswa Muslim Indonesia (KAMMI) yang pada tahun 1998 ikut aktif menyuarakan gerakan reformasi. Setelah terjadi pergantian pemerintahan dari Orde Baru ke Orde Reformasi selanjutnya mereka mendeklarasikan partai politik bernama Partai Keadilan (PK). Selanjutnya parpol ini menjadi kontenstan Pemilihan Umum 1999 dan tidak mampu menembus ambang batas (electora threshold) untuk bisa menjadi peserta pemilu berkutnya. Lalu parpol ini menyempurnakan diri dan mengubah nama menjadi Partai Keadilan Sejahtera (PKS).

Sebagai organisasi yang bergerak di bidang politik tentu memiliki budaya organisasi sebagai internal values sebagai fundamen dalam membangun eksistensi dan aktivitas kader dalam membesarkan organisasi. Apalagi PKS sebagai organisasi politik yang dimotori anak-anak muda terdidik lulusan perguruan tinggi Indonesia bahkan banyak pula lulusan luar negeri tentu telah menyiapkan budaya organisasi. Budaya organisasi yang bisa dipahami sebagai keseluruhan pengetahuan manusia sebagai makhluk sosial yang dipergunakan untuk memahami lingkungan serta pengalamannya dan menjadi pedoman tingkah lakunya. Dalam hal ini maka PKS sudah mengonstruksi norma, nilai,sikap dan keyakinan yang dimiliki bersama oleh anggota sejak awal 
mendirikan partai. Disamping itu sedari awal dimotori para mantan aktifis mahasiswa muslim di kampus telah menentukan pula visi dan misi partai yang hendak direalisasikan dalam kehidupan berbangsa dan bernegara.

Budaya organisasi dapat diibaratkan konteks yang selalu melingkupi kehidupan internal organisasi yang berimplikasi pada sikap perilakau dan aktivitas kader yang dikelola dalam kepengurusan dari tingkat pusat hingga kelurahan/desa. Oleh karena itu menjadi urgen keberadaan budaya organisasi sebagai suatu iklim komunikasi yang berakar pada seperangkat norma yang sama dan skema interpretatif tentang gejala-gejala yang terjadi ketika seseorang bekerja untuk mencapai tujuan tertentu (Carbaugh; dlm Liliweri,2004:326). Artinya PKS sebagai organisasi yang besar sudah menempatkan budaya organisasi sebagai kebutuhan utama untuk membangun kerja kelembagaan maupun dinamika aktivitas kader yang dikelola untuk mewujudkan visi misi partai. Selanjutnya budaya organisasi sebagai kekuatan internal sekaligus modal lembaga untuk mewujudkan visi misi partai harus dapat dievaluasi keberadaan dan peran bagi upaya mewujudkan visi misi organisasi.

\section{Budaya Organisasi dalam PKS}

Partai Keadilan Sejahtera (PKS) sebagai organisasi yang bergerak di bidang sosial politik adalah merupakan kumpulan sejumlah orang (anggota) dengan latar belakang pendidikan, sosial ekonomi, kepribadian, emosi dan ego yang beragam diantara seluruh anggota dalam berinteraksi kesehariannya. Kemajemukan dan interaksi kontinyu tersebut pada dasarnya akan membentuk budaya organisasi. Oleh sebab itu pengertian awal dari budaya organisasi adalah keseluruhan pengetahuan manusia sebagai makhluk sosial yang dipergunakan untuk memahami lingkungan serta pengalamannya dan menjadi pedoman tingkah laku (tindakan) keseharian dalam organisasi tersebut. Demikian pula yag terdapat di dalam PKS adalah pemahaman anggota dan terutama pengurus tentang norma, nilai, sikap dan keyakinan yang dimiliki bersama anggota, serta implementasi dan peran budaya organisasi dalam aktivitas organisasi untuk mewujudkan visi misi institusi.

Menurut Carbaugh (dlm Liliweri,2004;326) bahwa budaya organisasi juga merupakan iklim komunikasi yang berakar pada seperangkat norma yang sama dan skema interpretatif tentang gejala-gejala yang terjadi ketika seseorang (anggota) bekerja untuk mencapai tujuan tertentu. Dalam hal ini tujuan bersama yang ingin direalisasikan merupakan visi dan misi PKS sebagai organisasi sosial politik. Selanjutnya budaya organisasi juga meliputi struktur organisasi yang mengatur adat kebiasaan dan aturan kerja dalam organisasi. Maka dalam penelitian ini budaya organisasi yang diteliti termasuk struktur kelembagaan partai serta adat kebiasaan yang dibangun pengurus serta regulasi partai sebagai aturan kerja dalam partai sebagai upaya mewujudkan visi dan misi.

Adapun dalam budaya organisasi terdapat dua aspek yakni aspek materiil yang berujud meja, kursi, perangkat telepon, IT, lampu, arsitektur bangunan, dan lainnya yang bersifat fisik. Dan juga aspek non materiil seperti nilai, norma, kepercayaan, keyakinan, bahasa organisasi yang bersifat abstrak. Dan yang akan menjadi focus penelitian adalah pada aspek non materiil, karena budaya organisasi terutama yang non materiil sangat mempengaruhi anggota organisasi secara individu maupun kelompok. Berikutnya menurut Harrison (dlm Liliweri,2004;329-331) terdapat beberapa jenis budaya organisasi yag sering terdapat di dalam suatu institusi, diantaranya: (1) budaya kekuasaan yang terpusat/sentralistik, siapapun yag ada dalam jaringan organisasi tergantung pada sumber kekuasaan sentral (misalnya pengurus teras). Efektifitas organisasi sering diputuskan oleh figur sentral yang menentukan pembenaran atas maksud dan cara mereka menjalankan organisasi. 
budaya peran yang mengutamakan peran individu dalam struktur maupun keanggotaan dalam organisasi. Seluruh aktivitas diatur dan dikontrol oleh prosedur, deskripsi peran dan fungsi kewenangan. Budaya peran cenderung berkembang dalam suasana lingkungan yang relative stabil. Kemudian (3) budaya tugas yang diibaratkan jaringan dengan kekuatan pada teamwork yang berinteraksi satu dengan lainnya. Dan yang (4) budaya personal yang mengutamakan individu sebagai pusat yang diperhatikan dalam menjalankan tugas pada organisasi (individual centred).

\section{Pola Internalisasi dan Implementasi Visi Misi Partai}

PKS sebagai organisasi politik yang lahir pasca reformasi 1998 lalu merupakan sekumpulan anggota, kader dan pengurus yang bersifat structural dari pusat sampai ke daerah tepah menetapkan tujuan partai sebagaimana tertuang dalam Anggaran Dasar pasal 5 yakni: (1) "terwujudnya cita-cita nasional bangsa Indonesia sebagaimana dimaksud dalam pembukaan UUD negara Republik Indonesia tahun 1945” dan (2) "terwujudnya masyarakat madani yang adil dan sejahtera yang diridloi Allah SWT dalam bingkai Negara Kesatuan Republik Indonesia” (Maret 1998). Tujuan partai ternyata diderivasikan ke dalam visi dan misi partai yang akan direalisasikan dalam kehidupan bermasyarakat, berbangsa dan bernegara dari posisi sebagai salah satu partai politik di negeri ini.

Adapun visi Indonesia yang dicita-citakan Partai Keadilan Sosial adalah "terwujudnya masyarakat madani yang adil, sejahtera, dan bermartabat". Substansi dari visi tersebut dapat dieksplanasikan ke dalam tiga dimensi yakni: (a) masyarakat madani adalah masyarakat yang berperadaban tinggi dan maju yang berasaskan pada:nilai-nilai, norma, hukum, moral yang ditopang oleh keimanan; menghormati pluralitas; bersikap terbuka dan demokratis; dan bergotong royong menjaga kedaulatan negara. Selanjutnya (b) adil adalah kondisi dimana entitas dan kualitas kehidupan -baik pembangunan politik, ekonomi, hukum, dan sosial kemasyarakatanditempatkan secara proporsional dalam ukuran yang pas dan seimbang serta tidak melewati batas. Sedangkan yang (c) sejahtera diartikan mengarahkan pembangunan pada pemenuhan kebutuhan lahir dan bathin manusia dapat memfungsikan dirinya sebagai hamba dan khalifah Allah, yakni keseimbangan antara kebutuhan dan sumber pemenuhannya. Dan (d) bermartabat secara individual dan sosial menurut bangsa Indonesia untuk menempatkan dirinya sejajar dengan bangsa-bangsa lain di dunia. Martabat muncul dari akhlak dan budi pekerti yang baik, mentalitas, etos kerja dan akhirnya bermuara pada integritas kepribadian dan muncul dalam wujud produktivitas dan kreativitas.

Disinilah budaya organisasi merupakan fondasi untuk langkah dan tindakan untuk merealisasikan visi tersebut. Apalagi bahwa budaya organsasi meliputi nilai, norma dan moral sebagai aspek non materiil maupun aspek materiil yang berujud fisik sebagai sarana pendukung budaya organisasi.

Misi yang dilaksanakan PKS sebagai upaya mengimplementasikan visi partai adalah:

1. Memelopori reformasi system politik, pemerintahan dan birokrasi, peradilan, dan militer untuk berkomitmen terhadap penguatan demokrasi.

2. Mengentaskan kemiskinan, mengurangi pengangguran, dan meningkatkan kesejahteraan seluruh rakyat melalui strategi pemerataan pendapatan, pertumbuhan bernilai tambah tinggi, dan pembangunan berkelanjutan yang dilaksanakan melalui langkah-langkah utama. 
3. Menuju pendidikan berkeadilan dengan memberikan kesempatan yang seluas-luasnya bagi seluruh rakyat Indonesia. Membangun system pendidikan nasional yang terpadu, komprehensif dan bermutu untuk menumbuhkan SDM yang berdaya saing tinggi serta guru yang professional dan sejahtera.

Visi dan misi organisasi menjadi tanggungjawab bersama anggota dan pengurus dari pusat sampai ke daerah bahkan lingkup terkecil kelurahan dan desa, untuk mewujudkan dalam kehidupan sosial kemasyarakatan. Adapun upaya untuk mewujudkannya dalam konteks budaya organisasi maka terdapat tagline semacam jargon sebagai wacana untuk memperkuat keyakinan dan nilai yang memotivasi anggota untuk mewujudkan visi misi yakni "berkhidmat untuk rakyat" yang diartikan segala tindakan dan langkah perbuatan untuk melayani masyarakat. Supaya setiap langkah dan tindakan anggota betul-betul memberikan values dan impact kepada publik. Hal demikian sesuai konsepsi budaya organisasi dari Stoner (dlm FX Suwarto;2009:2) yakni sejumlah pemahaman penting seperti norma, nilai, sikap dan keyakinan yang dimiliki bersama oleh anggota organisasi.

Tagline ini bersifat fleksibel karena menyesuaikan perkembangan konteks di luar organisasi. Sehingga merupakan perubahan dari tagline sebelumnya yang dikenal dengan "bersih, peduli dan profesional" yang lebih bertujuan capacity building kelembagaan. Tagline sekarang ini dalam rangka penguatan eksistensi partai setelah menjadi kontestan empat kali pemilu. Pada praktiknya maka realisasi misi partai sebagai organisasi adalah melalui kerja kedewanan yang meliputi fungsi legislative, budgeting dan controlling bagi anggota partai yang menjadi legislator di DPR. Adapun ketiga fungsi yang dijalankan meliputi pembelaan kepentingan masyarakat melalui kebijakan atau regulasi pro sosial, seperti Perda Penanggulangan Kemiskinan di Kota Semarang. Disamping anggota legislatif yang ikut menyusun anggaran pro rakyat melalui penyusunan alokasi dana yang cukup bagi masyarakat, seperti dana BOS dan bantuan untuk lembaga pendidikan swasta. Sedangkan berkhidmat untuk rakyat diwujudkan dalam kerja anggota dewan mengawasi kinerja pemerintah kota Semarang dalam melayani masyarakat sampai pelaksanaan pembangunan seperti waduk Jatibarang dan Sungai Banjir Kanal Timur, bahkan membuka posko aduan atau keluhan layanan dokumentasi kependudukan seperti KTP, Akte Kelahiran, Sertifikat dan sebagainya.

Selanjutnya, visi dan misi organisasi diinternalisasikan kepada anggota atau kader melalui pola komunikasi yang mapan dalam dua format yakni; (1) direct communication melalui komunikasi dialogis dalam suatu pertemuan dengan partisipan pengurus, anggota maupun kader. Format komunikasi langsung dalam pertemuan juga dalam rangka merealisasikan PKS sebagai partai dakwah yang mengusung nilai-nilai keagamaan untuk disampaikan kepada anggota maupun simpatisan. Kemudian (2) communication by social media yang lebih merupakan jaringan antar individu di dalam keanggotaan partai, yang dapat berinteraksi secara kontinyu, seperti facebook, whatsapp, instagram. Hal ini menunjukkan budaya melek teknologi komunikasi atau media yang dibangun bagi anggota atau kader partai. Adapun untuk sosialisasi visi misi maka PKS mempergunakan komunikasi publik yakni penyampaian pesan kepada khalayak luas di luar anggota organisasi agar menjadi pengetahuan umum. Perwujudan dari komunikasi publik tersebut adalah PKS membangun social networking dan partnership (kerjasama) dengan seluruh elemen sebagai eksternal stakeholders di kota Semarang. Misalnya LSM, PKK, akademisi, kelompok pengajian, paguyuban sosial.

Disamping PKS berupaya melakukan kerja nyata pelayanan kepada masyarakat sebagai indikator sosialisasi sekaligus implementasi visi misi organisasi. Pemahaman sebagai substansi dari internalisasi visi misi 
kepada anggota dan pengurus PKS dilakukan melalui diskursus secara intensif dalam forum internal sehingga dapat terjadi komunikasi antar individu. Bahkan untuk penguatan internalisasi juga dilakukan dalam format Focus Group Discussion (FGD) antara jajaran pengurus dengan akademisi atau pakar yang kompeten, tokoh masyarakat dan wartawan dalam rangka menerima kritik dan masukan untuk memperkuat eksistensi dan nilainilai yang ada di organisasi selama ini.

\section{Penguatan Budaya Organisasi}

Budaya organisasi yang merupakan sejumlah pemahaman penting seperti norma, nilai,keyakinan dan sikap maupun aspek materiil yang bersifat fisik. Untuk penguatan budaya organisasi yang berisikan nilai maka PKS menyusun ideologi organisasi. Jika mengacu dari konsepsi indeologi menurut Thompson (1990:18-19) adalah "sistem pemikiran, sistem keyakinan dan sistem simbol yang berhubungan dengan tindakan sosial dan praktik politik". Maka PKS melakukan kodifikasi nilai dan keyakinan sebagai budaya organisasi dan sekaligus menjadi "partai dakwah" yang mengusung Islam, dan Nasionalisme sebagai ideologi. Ideologisasi nilai dan posisioning partai dalam rangka memperkuat budaya organisasi bagi anggota sekaligus memperkuat kegiatan dakwah untuk menyampaikan ajaran Islam kepada masyarakat, diluar aktivitas yang berhubungan dengan politik dan kebijakan publik. Secara umum, ideology merupakan idea tau gagasan bagi seseorang atau kelompok yang menjadi pegangan atau prinsip dalam menjalani kehidupannya. Ideologi beroperasi dalam pikiran, perasaan yang dieskspresikan dalam ucapan, tulisan, tindakan dan perilaku langsung dan output lainnya (Udi Rusadi;2015:105).

Keberhasilan internalisasi ideologi organisasi PKS dibuktikan dengan perilaku, tindakan, loyalitas dan soliditas kader maupun anggota terhadap semangat berorganisasi maupun dakwah keagamaan yang telah menjadi "branding" partai dalam satu dekade terakhir. Adapun penguatan ideologi dilakukan secara terstruktur diawali dari pembentukan good personality elite kemudian pembinaan dan pengkajian secara intensif berbasis wilayah yang menjadi tanggungjawab pembina (tokoh PKS Kecamatan atau Daerah Pemilihan) bersama anggota. Disamping itu nuansa keagamaan dan perjuangan amat terasa pada setiap kegiatan yang digelar partai seperti; rapat rutin, bhakti sosial, pengobatan massal sampai pemberian bantuan bencana bahkan sampai demonstrasi besar mendukung kemerdekaan Palestina. Misalnya; simbol pakaian muslim, jargon Islam yang Kaffah, Anti Israel. Terkait ideology partai tersebut menurut M Shaughnessy \& Jane Stadler (2005; dlm Rusadi;2015:105) bahwa ideology dapat ditemukan di tiga tempat, pertama, ada dalam bahasa, teks dan repersentasi. Pada PKS ditemukan dalam bahasa Islami dan pernyataan yang disampaikan terkait kebijakan partai seperti: mendukung kemerdekaan Palestina, atau Perda Syariah di beberapa daerah. Kedua, ada pada kelembagaan material dan praktik-praktik yang berlangsung. Dalam hal ini PKS mampu menciptakan struktur partai yang bersifat hirarkhies dengan loyalitas dan soliditas anggotanya. Dan ketiga, ada dalam kepala dan hati. PKS melakukan internalisasi nilai dan norma organisasi dalam rangka ideologisasi di tubuh partai secara keseluruhan.

Penguatan budaya organisasi di PKS juga ditempuh melalui internalisasi nilai-nilai organisasi yang bersifat normatif untuk menjadi platform inovasi, sikap, tindakan dan langkah kader maupun anggota, seperti bersih, peduli dan professional. Eksplanasi dari bersih adalah diusahakan bagi setiap kader memiliki good personality yakni amanah dan akuntabel. Sedangkan peduli menekankan pada institusi yang memiliki sensitivitas terhadap lingkungan maupun masyarakat selaku konstituen, disamping itu anggota dan kader juga 
memiliki kepedulian terhadap lingkungan tempat berdakwah dalam kesehariannya. Profesional lebih ditekankan kepada kader yang berada di legislatif maupun eksekutif untuk menunjukkan kerja yang kompeten, berintegritas, bertanggungjawab, disiplin dan sepenuh tenaga dan pikiran untuk menjalankan tugas di bidang pemerintahan dan pengambilan keputusan (government and polecy making) dalam rangka mengemban visi misi PKS. Hal ini dicontohkan kepada 6 anggota DPRD Kota Semarang dari PKS harus mampu menunjukkan kerja professional di dalam tugas kedewanan. Kepedulian partai bisa dilakukan secara structural sesuai agenda yang ditetapkan dari pusat sampai ranting untuk mewujudkan visi dan misi partai.

Penguatan nilai dan norma dalam interaksi sebagai bagian budaya organisasi di PKS adalah didasarkan etika religius yakni akhlak atau moral dan dakwah sebagai karaketristik partai. Etika religius diimplementasikan secara struktural yakni melalui institusi partai dengan pedoman Angaran Dasar/Anggaran Rumat Tangga (AD/ART) maupun gerakan kultural ke tengah masyarakat dengan berdakwah. Oleh karena itu penguatan budaya organisasi di PKS dilakukan melalui tiga model, yakni internalisasi kepada setiap pribadi kader maupun anggota, kemudian penguatan di dalam setiao keluarga serta eksternalisasi melalui gerakan dan tindakan nyata untuk merealisasikan visi misi partai.

\section{Bentuk Budaya Organisasi}

Berikutnya, bentuk budaya organisasi yang telah diperkuat baik secara struktural maupun kultural yang diwujudkan kader maupun anggota PKS terbagi ke dalam aspek non materiil yang bersifat abstrak maupun materiil yang bersifat fisik. Menurut Littlejohn (2009:383) bahwa budaya organisasi adalah sesuatu yang dihasilkan melalui interaksi sehari-hari dalam organisasi, bukan hanya tugas pekerjaan, tetapi semua jenis komunikasi. Selain itu menurut John Van Maanen \& Stephen Barley (dlm Littlejohn:382) bahwa dalam budaya organisasi terdapat bidang konteks ekologis (ecological context) adalah dunia fisik, termasuk lokasi, waktu dan sejarah, dan konteks sosial (social context) yang di dalamnya organisasi berjalan. Termasuk pada organisasi PKS dapat dieksplanasikan sebagai berikut;

Pertama, budaya organisasi non fisik yang dapat berperan merealisasikan visi misi partai diwujudkan dalam pembentukan sikap yang dibingkai dalam tagline "berkhidmat untuk rakyat". Adapun sikap tersebut dipraktikkan ke dalam dua konteks yakni konteks internal keumatan dan konteks umum yakni kerakyatan. Artinya partai dalam mewujudkan visi misi dengan dukungan peran budaya yang dapat mengover keumatan (Islam) sekaligus kerakyatan (masyarakat kota Semarang), melalui sikap moderat-akomodatif antara keislaman dan keindonesiaan. Misalnya mengakomodir budaya Semarangan: gotong royong, guyub rukun dan moderat sekaligus ukhuwah islamiyah di tengah kaum muslimin.

Kedua, budaya musyawarah mufakat dalam membahas suatu persoalan maupun mencari solusi. Membahas suatu aktivitas melalui dukungan ICT diantara pimpinan partai maupun rapat pimpinan (musyawarah) kemudian hasilnya di-share kepada kader dan setelah memperoleh dukungan persetujuan (mufakat) kemudian ditindaklanjuti dalam aktivitas yang melibatkan kader dan anggota. Misalnya sikap mendukung pemerintah kota Semarang pasca pelantikan walikota, meskipun sebelumnya dalam Pilkada mengalami kekalahan. Atau keputusan mengadakan kegiatan bhakti sosial kepada masyarakat.

Ketiga, budaya kekeluargaan, yakni budaya membangun kebersamaan dalam satu keluarga besar melalui nilai ukhuwah Islamiyah maupun persahabatan sesama kader, anggota maupun simpatisan PKS. Sehingga muncul sikap saling membantu, bekerjasama dalam menjalankan aktivitas kemasyarakatan. Budaya 
kekeluargaan yang berhasil dibangun telah menjadi image soliditas dan loyalitas kader partai selama ini dibanding partai lain.

Keempat, membangun keyakinan akan nilai yang tercantum dalam visi misi partai kepada kader dan anggota melalui internalisasi dan penguatan secara kontinyu dengan memanfaatkan struktur partai, forum pertemuan maupun dukungan ICT karena melek IT diantara kader partai. Penguatan terhadap tagline "berkhidmat untuk rakyat" serta posisioning partai dakwah yang terus melayani kepentingan masyarakat sekitarnya. Keberhasilan membangun keyakinan tentang visi misi partai telah menciptakan sikap loyal, militant dan solid pada kader maupun anggota dalam menghadapi tantangan partai selama ini.

Kelima, agar supaya budaya organisasi berperan maka diciptakan nilai dalam dinamika organisasi yang menjadi acuan perilaku kader dan anggota yakni: egaliter (kesederajatan), terbuka dengan sesama, rasional, friendship (persahabatan), sederhana dan patuh pada keputusan dan aturan yang berlaku.

Keenam, bentuk budaya organisasi di PKS yang lain yakni membangun kecakapan personal dalam berkomunikasi (kompetensi komunikasi) dengan pilihan bahasa yang mampu mendukung dan berperan dalam merealisasikan visi misi partai. Kader dididik untuk cakap berkomunikasi publik dengan diksi yang mudah dan komunikatif untuk meyosialisasikan visi misi partai. Termasuk dalam mengeliminasi image partai “eksklusif” perilaku anggota yang "tertutup" dan sulit berinteraksi dengan kemajemukan masyarakat saat ini.

Selanjutnya, bentuk budaya organisasi yang berwujud materiil adalah DPD PKS Kota Semarang pada 2013 telah membangun kantor partai secara permanen, yang didirikan dengan memberdayakan potensi internal secara mandiri yakni iuran gotong royong seluruh kader dan anggota. Disamping itu terdapat dukungan eksternal dari simpatisan yang ikut mewujudkan kantor partai sebagai pusat aktivitas politik maupun keumatan dalam keseharian. Selanjutnya kantor dengan sebutan "Markas Dakwah" berada di kelurahan Puspanjolo Kecamatan Semarang Barat.

Pada kantor partai sudah dilengkapi sarana prasarana pendukung aktivitas seperti: meja kursi, berbagai ruang pertemuan, fasilitas internet (WiFi), komputer lengkap database organisasi, ruang pengurus sesuai bidang dalam struktur organisasi, lampu penerangan, arsitektur bangunan tiga lantai sampai lahan parkir yang memadai. Bahkan partai sejak 2010 memiliki mobil ambulance "gratis" untuk memberikan pelayanan kepada masyarakat. Kantor partai sekaligus dimanfaatkan sebagai posko khidmat dan posko rumah keluarga dengan misi siapapun yang masuk akan mendapatkan kenyamanan dan pelayanan dengan baik, supaya budaya organisasi dapat mempengaruhi anggota secara individu maupun kelompok. Disamping itu, budaya organisasi juga dibangun dari aspek materiil melalui tampilan fisik dengan pakaian muslim (gamis), merawat jenggot, pemakaian siwak, berjilbab bagi perempuan dan selalu membawa kitab suci. Konteks pertemuan dan interaksi selalu dibangun dalam suasana religius, misalnya panggilan antum, ikhwan, akhwat, bacaan AlQur'an serta pekik takbir dalam setiap pertemuan.

\section{Budaya Organisasi dalam Struktur Partai}

Struktur organisasi partai yang menunjukkan terdapat hirarkhie maupun diferensiasi otoritas dan tanggungjawab pemegang jabatan didalamnya membutuhkan pula budaya organisasi. Dalam hal ini menurut Liliweri (2004:326) bahwa budaya organisasi juga meliputi struktur organisasi (yang mengatur adat kebiasaan dan aturan kerja). Struktur dan rumusan (nilai) ini membimbing anggota untuk berinteraksi satu sama lain diatara mereka dan bagaimana mereka berkomunikasi dengan orang-orang dari budaya organisasi yang lain 
(pihak eksternal). Sebagaimana struktur kelembagaan DPD PKS Kota Semarang maka dapat dianalisis bahwa terdapat : Dewan Pimpinan Daerah terdiri dari Majelis Pertimbangan Daerah, Dewan Pengurus Daerah dan Dewan Syariah Daerah. Sedangkan DPD dipimpin seorang ketua umum dibantu wakil ketua umum lalu dibawahnya terdapat sekretaris umum dan bendahara. Kemudian diperkuat ketua dan lima belas bidang karena berada di ibukota propinsi sehingga bertipe A. Tugas pokok pengurus telah diatur dalam AD/ART partai.

Disamping manajemen partai dikelola secara good management dan modern. Pengurus menetapkan untuk mendinamisasi organisasi maka seminggu sekali diselenggarakan pertemuan untuk membahas perkembangan partai maupun dinamika kemasyarakatan di Kota Semarang. Pada tingkatan struktur maka dibangun budaya rasa bangga pada partai (sense of belonging) dan kultur berlomba-lomba dalam kebaikan (fastabiqul khoirot) diantara sesama pengurus DPD. Budaya ini dalam rangka menghadapi perilaku pragmatismaterialistik yang mengandalkan kapital dalam berpolitik.

Budaya organisasi dalam mengelola kepengurusan partai maka terdapat aktor yang menjadi pusat manajemen. Yakni terdapat aktor struktural terdiri dari mereka yang duduk di jajaran pimpinan organisasi (DPD). Mereka menjadi sumber alur komunikasi serta gagasan dan informasi program kerja maupun kebijakan partai. Kemudian aktor kultural yakni mereka yang memimpin unit-unit pembinaan dibawah organisasi, dan langsung berhubungan dengan realitas di masyarakat. Kedua aktor bersinergi menjalankan kebijakan partai untuk merealisasikan visi misi organisasi.

Selanjutnya untuk merealisasikan visi misi partai, maka kepengurusan terdapat upaya membangun jaringan sosial (social networking) maupun stakeholder yakni elemen masyarakat maupun komponen bangsa yang majemuk, termasuk di Kota Semarang. Partai membangun interaksi dan komunikasi politik dengan organisasi lain, tokoh masyarakat, tokoh agama, akademisi, LSM, organisasi kemahasiswaan dan kepemudaan, komunitas nelayan, media dan wartawan serta kelompok kritis yang terdapat di kota Semarang. Untuk memudahkan merajut jaringan sosial maka PKS mengedepankan nilai kebangsaan yang mengakomodir kemajemukan (nasionalisme - pluralism) di masyarakat kota Semarang. Hal demikian juga dalam mengikis pandangan tentang perilaku eksklusif dan tertutup serta anti pluralism yang sering menjadi sorotan publik kepada PKS. Oleh karena itu DPD PKS membekali kader kompetensi komunikasi dan bersikap terbuka terhadap kritik dari pihak manapun. Misalnya pada Milad PKS tahun 2016 DPD PKS bertempat di Kantor telah mengundang LSM, wartawan dan pemerhati politik untuk memberikan kritik dan koreksi terhadap keberadaan dan kerja-kerja PKS di masyarakat. Salah satu yang mengemuka adalah pandangan "minor" terhadap PKS yang masih tertutup, anti pluralism dan eksklusif. Disamping itu pada pengelolaan struktur partai masih terdapat budaya "menghormati" senior yang merupakan peletak fondasi dan platform partai dari awal, seperti pendiri atau deklarator partai. Meski demikian tetap melanjutkan budaya regenerasi secara kontinyu dan berkesinambungan. Misalnya melalui mekanisme musyawarah daerah (Musda) untuk pergantian kepemimpinan maupun pengurus di tingkat kota. 
Apabila digambarkan secara mekanisme maka peran budaya organisasi di PKS dalam mewujudkan visi misi partai dapat dijelaskan sebagai berikut:

\begin{tabular}{|c|c|c|c|}
\hline Budaya Organisasi : & Intemalisasi ke kader : & Pembentukan & Realisasi \\
\hline $\begin{array}{l}\text { - Nilai-nilai organisasi } \\
\text { - Keyakinan / Komitmen } \\
\text { - Ideologi } \\
\text { - Kepemilikan materiil } \\
\text { (kantor \& kelengkapannya) }\end{array}$ & $\begin{array}{l}\text { - Sosialisasi } \\
\text { - Dinamisasi }\end{array}$ & $\begin{array}{l}\text { - Pola pikir } \\
\text { - Sikap } \\
\text { - Perilaku } \\
\text { - Langkah / Tindakan } \\
\text { Kader / Anggota }\end{array}$ & $\begin{array}{l}\text { - Visi/Misi } \\
\text { - Partai }\end{array}$ \\
\hline
\end{tabular}

\section{Peran Budaya Organisasi}

Peran budaya organisasi yang dibangun pada institusi PKS dalam mewujudkan visi misi partai sejak berdiri dapat dijelaskan sebagai berikut:

Pertama, peran budaya organisasi yang diciptakan merupakan bagian prinsip fundamental dalam pembentukan jatidiri dan karakter kader maupun anggota melalui pola pikir atau mindset. Jatidiri kader partai dakwah yang siap melayani umat, dengan karakter keislaman yang jelas di tengah kemajemukan Indonesia.

Kedua, budaya organisasi berperan mengarahkan (orientasi) pembentukan sikap dan perilaku kader dalam menjalankan aktivitas organisasi maupun interaksi bermasyarakat berbangsa dan bernegara. Sikap keder yang menunjukkan nasionalisme (kebangsaan) sekaligus keislaman sebagai nilai dalam organisasi sejak didirikan pada 20 Agustus 1998.

Ketiga, budaya organisasi juga berperan memotivasi loyalitas dan soliditas kader dan anggota dalam menjalankan aktivitas program untuk mewujudkan visi misi partai, sehingga langkah dan tindakan kader merepresentasikan keberadaan partai. Loyalitas ditunjukkan dengan kesetiaan dan kepatuhan terhadap apapun putusan pimpinan partai, misalnya: unjuk rasa mendukung kemerdekaan Palestina, Menolak Terorisme, Menolak UU Pornografi.

Keempat, budaya organisasi ikut mempengaruhi penguatan keyakinan dan komitmen kader kepada partai baik secara struktural (hirarkhies) maupun kultural diantara kader dan anggota partai. Faktor ini menjadikan kader PKS memiliki karakteristik khusus seperti militansi dan daya tahan dalam menjalankan aktivitas organisasi menghadapi tantangan eksternal, misalnya: persepsi tentang sikap eksklusif, tertutup dan anti pluralism. Kader lebih yakin terhadap nilai dan ideology yang telah diinternalisasikan partai selama ini.

Kelima, budaya organisasi telah ikut mengarahkan sikap dan tindakan pimpinan organisasi secara hirarkhies sehingga memperkuat soliditas partai. Budaya musyawarah mufakat dan kepatuhan terhadap putusan pimpinan tertinggi menjadikan apapun kebijakan partai didukung bersama, seperti pergantian ketua umum melalui musyawarah nasional. Partai terbukti minim konflik inter personal dan tidak pernah dilanda konflik berkepanjangan yang berakibat memecah keutuhan partai.

Keenam, budaya organisasi telah memperkuat sense of belonging terhadap partai sekaligus kepatuhan terhadap keputusan dan kebijakan partai dalam menjalankan program untuk mewujudkan visi misi partai. Seperti keputusan DPD PKS Kota Semarang untuk mendukung kepemimpinan Pemerintah Kota pasca Pilkada 2015 lalu, dipatuhi kader maupun anggota dengan menunjukkan sikap dukungan dari DPRD. 


\section{KESIMPULAN}

1. Visi Partai Keadilan Sejahtera (PKS) yang diperjuangkan kader dan seluruh anggota untuk Indonesia adalah "Terwujudnya masyarakat madani yang adil, sejahtera dan bermartabat".

2. Misi yang diusung Partai Keadilan Sejahtera dan merupakan breakdown dari visi adalah:

a. Memelopori reformasi sistem politik, pemerintahan dan birokrasi, dan militer untuk berkomitmen terhadap penguatan demokrasi.

b. Mengentaskan kemiskinan, mengurangi pengangguran, dan meningkatkan kesejahteraan seluruh rakyat melalui strategi pemerataan pendapatan, pertumbuhan bernilai tambah tinggi dan pembangunan yang berkelanjutan.

c. Menuju pendidikan berkeadilan dengan memberikan kesempatan yang seluas-luasnya bagi seluruh rakyat Indonesia.

3. Internalisasi visi dan misi partai dilakukan melalui komunikasi dengan dua pola yakni, (1) komunikasi dialogis yang memberi kesempatan mendiskursuskan visi misi partai kepada kader maupun anggota melalui dialog terbuka, rasional dan timbale balik diantara kader maupun anggota partai. Dan (2) visi misi juga diinternalisasikan secara kontinyu melalui media sosial, dengan argumentasi bahwa kader dan anggota PKS melek ICT sehingga dijadikan salah satu media komunikasi diantara kader termasuk dalam internalisasi visi misi partai.

4. Adapun sosialisasi visi misi partai agar dikenal dan dipahami publik maka dilakukan melalui: Pertama, komunikasi publik yakni menyampaikan visi misi partai kepada masyarakat secara langsung (direct communication) dalam forum pertemuan. Misalnya dilakukan anggota DPRD PKS di Daerah Pemilihannya. Dan juga melalui komunikasi massa yakni menyampaikan visi misi partai dengan memanfaatkan media massa (cetak maupun elektronik) dengan format kegiatan maupun pernyataan pengurus di hadapan media. Kedua, visi misi partai dikomunikasikan kepada organisasi atau elemen masyarakat lain (inter organizations) melalui jaringan sosial dan relasi dengan elemen lain. Misalnya dengan ormas agama, tokoh masyarakat, media, kampus, kelompok kritis. Kemudian ketiga, visi misi disampaikan melalui kerja riil dalam bentuk pelayanan kepada masyarakat, misalnya bantuan bencana alam, bhakti sosial, penyediaan ambulance gratis, daerah binaan dakwah, kemah bhakti, dan sejenisnya.

5. Nilai-nilai organisasi dalam Partai Keadilan Sejahtera meliputi:

- Keislaman, sebagai asas pendirian partai sekaligus ajaran yang dipraktikkan dalam keseharian maupun didakwahkan anggota kepada masyarakat. Nilai keislaman ditunjukkan dalam perilaku anggota maupun aktivitas partai bahkan sampai simbol-simbol keagamaan sebagai performa kader maupun anggota, misalnya: cara berpakaian, ucapan salam, pekik takbir sampai bacaan Al Qur'an dalam setiap forum pertemuan partai.

- Egalitarianisme: menempatkan seluruh anggota dan kader pada posisi yang sederajat di dalam berorganisasi dan menjalankan aktivitas. Perlu dijelaskan kader adalah anggota partai yang sedang mengemban amanah sebagai pengurus dari tingkat pusat sampai ranting yang berada di kelurahan bahkan sampai RW/RT. Dan kader dipastikan merupakan anggota partai. Sedangkan anggota adalah individu-individu yang menjadi anggota resmi partai dengan bukti kepemilikan kartu anggota partai.

- Terbuka artinya pola komunikasi diantara kader maupun anggota maka pesan-pesan yang disampaikan bersifat apa adanya terkait dengan kebijakan dan rencana program kerja dan aktivitas partai. Sehingga bisa diketahui secara terbuka oleh anggota. 
- Rasional, dalam menjalankan aktivitas organisasi selalau dalam pertimbangan yang masuk akal, argumentatif dan berdasarkan bukti-bukti yang dapat dipertanggungjawabkan dalam berkomunikasi diantara anggota partai.

- Musyawarah, setiap perencanaan aktivitas maupun persoalan yang terdapat di dalam partai dibicarakan bersama melalui forum pertemuan yang memberi kesempatan kader maupun anggota menyampaikan pandangan dan pendapat pribadinya, untuk dijadikan fundamen menciptakan kesepakatan.

- Patuh kepada pimpinan, apapun keputusan dan kebijakan yang diambil pimpinan partai sesuai hirarkhie maka dipatuhi oleh kader dan anggota untuk dilaksanakan dalam rangka mewujudkan visi misi partai. Misalnya putusan pimpinan untuk kegiatan bhakti sosial di hari libur maka pasti ditaati anggota untuk dilaksanakannya.

- Taat terhadap aturan yang berlaku yakni menciptakan rasa taat pada aturan dan asas partai yang berlaku dan mengikat kader maupun anggota dalam menjalankan roda organisasi.

- Nasionalisme - pluralism artinya PKS Kota Semarang menekankan nilai wawasan kebangsaan sebagai wujud rasa cinta tanah air, dalam kehidupan bermasyarakat, berbagsa dan bernegara kepada seluruh kader maupun anggota. Termasuk kesiapan menerima kemajemukan di Kota Semarang, oleh karena itu kader PKS dibekali kompetensi komunikasi agar dapat berinteraksi dengan elemen lain di Kota Semarang.

6. Bentuk budaya yang dibangun dalam Partai Keadilan Sejahtera adalah diawali dari budaya sikap yang berorientasi dari nilai-nilai organisasi yang diinternalisasikan kepada kader dan anggota. Sikap pada individu tersebut secara keseluruhan dapat merepresentasikan budaya organisasi seperti sikap patuh kepada pimpinan dan taat aturan yang berlaku dalam partai. Disamping sikap juga disertai keyakinan anggota kepada nilai-nilai organisasi yang telah diinternalisasikan secara kontinyu. Misalnya, mandiri, disiplin dan peduli. Selanjutnya budaya musyawarah-mufakat yang membiasakan anggota bermusyawarah membahas permasalahan atau program kerja partai yang harus dilaksanakan bersama. Untuk dapat mewujudkan visi misi partai, maka dibangun budaya kekeluargaan yang selama ini menjadi kelebihan organisasi. Kebersamaan dan rasa kekeluargaan antar anggota dan kader telah menciptakan soliditas organisasi.

7. Upaya penguatan (empowering) budaya organisasi di tubuh PKS dilaksanakan diantaranya adalah: pertama, ideologisasi nilai-nilai organisasi sekaligus positioning sebagai partai dakwah yang mengusung tagline "berkhidmat untuk rakyat" agar dapat melayani masyarakat dalam frame dakwah keislaman. Misalnya membentuk daerah binaan dan forum kajian agama di lingkungan sekitar. Kedua, internalisasi nilai organisasi ditujukan kepada kader yang masuk di lembaga legislatif maupun eksekutif, kader di kepengurusan struktural dan anggota di tingkat anak cabang sampai ranting. Ketiga, realisasi visi misi melalui kerja-kerja nyata kader dan anggota yakni budaya kerja sebagai perwujudan pelayanan kepada masyarakat. Misalnya menyelenggarakan bhakti sosial, bersih-bersih Kota Semarang, pelayanan dakwah, gotong royong renovasi lokasi makam.

8. Peran budaya organisasi dalam mewujudkan visi misi partai, maka dapat disimpulkan sebagai berikut:

a. Budaya organisasi yang ada berperan dalam membentuk jati diri dan karakter anggota partai dalam melaksanakan aktivitas maupun interaksi bermasyarakat, berbangsa dan bernegara. Jati diri sebagai kader partai Islam yang peduli dan professional dalam melayani masyarakat. 
b. Budaya organisasi di PKS memiliki peran memberikan orientasi atau arahan dalam pembentukan sikap dan langkah tindakan anggota dalam aktivitas untuk mewujudkan visi misi partai. Orientasi dipandu nilai-nilai yang telah diinternalisasikan melalui struktur partai kepada anggota.

c. Budaya organisasi juga berperan dalam mendorong loyalitas maupun soliditas anggota partai dalam menjalankan aktivitas maupun berkiprah di partai selama ini. Loyalitas ditunjukkan dengan kepatuhan dan ketaatan kepada kebijakan dan keputusan pimpinan partai tentang suatu permasalahan atau kerjakerja partai.

d. Budaya organisasi di PKS berperan dalam penguatan keyakinan individu anggota yang berefek pada sense of belonging (rasa memiliki) terhadap partai yang berdiri sejak 1998 lalu. Rasa bangga anggota kepada partai ditandai dengan soliditas dan kepatuhan anggota melaksanakan keputusan organisasi, misalnya: kegiatan gotong royong bersih kampung maupun pelayanan sosial kepada masyarakat Kota Semarang.

e. Budaya organisasi yang dibangun memengaruhi orientasi sikap dan tindakan pimpinan organisasi dalam menjalankan kepengurusan, misalnya pengambilan keputusan dikomunikasikan dan didiskusikan dengan kader melalui musyawarah partai dalam bentuk rapat atau pertemuan berkala di kantor sekretariat. Misalnya rapat pengambilan keputusan untuk mendukung pemerintah Kota Semarang pasca pemilihan kepala daerah 2015 lalu. 


\section{DAFTAR PUSTAKA}

Alo Liliweri, Wacana Komunikasi Organisasi, CV Mandar Maju, Bandung,2004

Andre Hardjana, Audit Komunikasi Organisasi, PT Grasindo, Jakarta, 2000

Anwar Arifin, Komunikasi Politik, PT Graha Ilmu, Yogyakarta, 2011

Madu, Boniface C.(2012). Organization culture as driver of competitive advantage. Journal of Academic and Business Ethics 5 (pg 1-9). Academic and Business Research Institute (AABRI)

Moleong, Lexy J.(1991). Metodologi Penelitian Kualitatif. Bandung: Remaja Rosdakarya.

Patton, Michael Quinn.(1991) Metode Evaluasi Kualitatif. Yogyakarta: Pustaka Pelajar

Pawito. (2007). Penelitian Komunikasi Kualitatif. Yogyakarta: LkiS

Rodan, Garry. (2014).Civil society activism and political parties in Malaysia: differences over local representation (pg.824-845). International Bibliography of the Social Sciences

Soetopo HB. (2002).Metode Penelitian Kualitatif; Dasar Teori dan Penerapannya dalam penelitian. Surakarta: UNS press.

Soewarto,FX, Budaya Organisasi (Kajian Konsep dan Implementasi), UAJY, Yogyakarta, 2009. 